\title{
Impact of emergency contraception status on unintended pregnancy: observational data from a women's health practice
}

\author{
Nalin PAYAKACHAT, Denise RAGLAND, Cherri HOUSTON.
}

Received (first version): 7-May-2010

Accepted: 21-Jul-2010

\begin{abstract}
${ }^{*}$
Objective: This study aimed to determine if nonprescription emergency contraception (EC) availability impacted self-reported unintended pregnancy rates and to assess women's knowledge and awareness of EC prior to and after nonprescription availability.

Methods: A survey regarding contraception use and knowledge was verbally administered to a crosssectional, convenience sample of 272 pregnant women receiving prenatal care at a large urban community women's clinic between August 2003 and October 2008. Statistical analyses determined the differences between two groups (before [BA] and after, $[A A]$ non-prescription EC availability in the U.S. drug market) in terms of self-reported unintended pregnancy rates, knowledge and awareness of EC.

Results: The AA group reported higher incidence of unintended pregnancy when compared to the BA group $(90.7 \%$ vs. $72.7 \%, P=0.0172)$. The majority of both groups reported that they were not using any contraception at the time of conception (BA$84.4 \%$; AA-83.3\%). There was no significant difference in the participants' awareness of EC between the two groups (BA- $46.8 \%$ vs. AA-43.0\%) nor was there a significant difference between the two groups in the self-reported willingness to use $\mathrm{EC}$ in the future (BA-53.1\% vs. AA-63.4\%). However, among participants who were unaware of EC, $61 \%$ reported they would consider using it in the future after receiving brief EC counseling from a pharmacist or student pharmacist. Neither age nor pregnancy intention was associated with selfreported EC awareness but there was an association with income $(P=0.0410)$ and education $(P=0.0021)$.

Conclusion: The change from prescription-only to non-prescription status of EC in the U.S. drug market did not impact the unintended pregnancy rate in this patient population. Lack of knowledge and awareness is still a major barrier to widespread EC use.
\end{abstract}

\footnotetext{
Nalin PAYAKACHAT. BPharm, MSc, PhD. Assistant Professor. Division of a Pharmaceutical Evaluation and Policy, Department of Pharmacy Practice. College of Pharmacy, University of Arkansas for Medical Sciences. Little Rock, AR (United States).

Denise RAGLAND. PharmD. Associate Professor. Department of Pharmacy Practice. College of Pharmacy, University of Arkansas for Medical Sciences. Little Rock, AR (United States).

Cherri HOUSTON. PharmD Candidate 2011. College of Pharmacy, University of Arkansas for Medical Sciences Little Rock, AR (United States).
}

Keywords: Contraception, Postcoital. Behind-theCounter Drugs. Health Knowledge, Attitudes, Practice. United States.

\section{IMPACTO DEL ESTADO DE LOS \\ CONTRACEPTIVOS DE EMERGENCIA EN \\ EL EMBARAZO INDESEADO: DATOS OBSERVACIONALES DE UNA CLÍNICA DE MEDICINA DE MUJER}

\section{RESUMEN}

Objetivo: Este estudio trató de determinar si la disponibilidad sin receta de la contracepción de emergencia (CE) impactó en la proporción autoreportada de embarazos no deseados y evaluar el conocimiento y consciencia de las mujeres sobre la $\mathrm{CE}$ antes y después de la disponibilidad sin receta. Métodos: Se administró verbalmente un cuestionario sobre uso y conocimiento a una muestra transversa de conveniencia de 272 mujeres embarazadas que recibían atención prenatal en una gran clínica urbana de mujeres entre agosto 2003 y octubre 2008. Los análisis estadísticos determinaban las diferencias entre dos grupos (antes [BA] y después [AA] de la disponibilidad de la $\mathrm{CE}$ sin receta en el mercado de medicamentos de Estados Unidos) en términos de tasas reportadas de embarazo no deseado, conocimiento y consciencia de la CE.

Resultados: El grupo AA reportó mayor incidencia de embarazo no deseado en comparación con el grupo BA $(90,7 \%$ vs. $72.7 \%, \mathrm{P}=0,0172)$. $\mathrm{La}$ mayoría en ambos grupos informó que no estaban utilizando ningún contraceptivo en el momento de la concepción (BA-84,4\%; AA-83,3\%). No había diferencia significativa en la consciencia de los participantes sobre la CE entre ambos grupos (BA$46,8 \%$ vs. AA $-43,0 \%$ ) ni había diferencia significativa en la voluntad auto-.reportada de utilizar CE en el futuro (BA-53,1\% vs. AA-63,4\%). Sin embargo, entre los participantes que no eran conocedores de la $\mathrm{CE}$, el $61 \%$ reportó que considerarían utilizarla en el futuro después de haber recibido un breve consejo de un farmacéutico o un estudiante de farmacia. Ni la edad, ni la intención de embarazo estaba asociada con la consciencia auto-reportada de la CE, pero había asociación con los ingresos $(\mathrm{P}=0,0410)$ y la educación $(\mathrm{P}=0,0021)$.

Conclusión: El cambio del estado de prescripción a sin receta de la CE en el mercado de medicamentos de los Estados Unidos no impactó en la tasa de embarazos indeseados en esta población de pacientes. La falta de conocimiento y consciencia 
de la CE es la mayor barrera para la diseminación del uso de CE.

Palabras clave: Contracepción postcoital. Medicamentos sin receta. Conocimiento, actitudes, practica sobre salud. Estados Unidos.

\section{INTRODUCTION}

Unintended pregnancy is a public health issue that warrants the attention of healthcare professionals and policy decision-makers. ${ }^{1,2}$ Determining the causes of these pregnancies and identifying methods to prevent them has the potential to greatly improve the health of women and their children. In 2001 , nearly $50 \%$ of all pregnancies in the Unites States were unintended, defined as mistimed or unwanted at the time of conception. ${ }^{1}$ Previous reports showed that one of every two females between 15 and 44 years of age has had at least one unintended pregnancy. ${ }^{1,3}$ Teens (15-19 years of age) are the age group at the greatest risk of unintended pregnancies. ${ }^{1,4,5}$ Additional risk factors include singlehood, race, low income, incompletion of high school, irregular contraception use, and being unaware of emergency contraception. 6,7 Arkansas has the 10th highest teenage pregnancy rate of all U.S. states; $13 \%$ of these teenage pregnancies in Arkansas result in abortions. ${ }^{8}$

An unintended pregnancy may result in morbidity and socio-economic challenges for the patient, the infant, and the families involved. ${ }^{9}$ A woman with an unintended pregnancy may experience domestic violence, suffer from depression, receive late prenatal care, and unwittingly expose the fetus to teratogens. ${ }^{1,6,9,10}$ Furthermore, an unintended pregnancy may cause one or both parents to alter their plans in pursuing an education with subsequent economic consequences. ${ }^{9}$ Adverse fetal outcomes associated with unintended pregnancy include low birth weight, neonatal death, child neglect, and abuse. ${ }^{6,9}$ According to the 2002 National Survey of Family Growth, medical expenses for unintended pregnancies cost approximately 5 billion US dollars per year in the U.S. ${ }^{6,11}$

Emergency contraception (EC) is defined as therapy used to protect against pregnancy after an unprotected or inadequately protected sexual intercourse. This therapy is a medically accepted method of contraception and may decrease unintended pregnancy rates. ${ }^{4,12}$ The Yuzpe method, first published in 1974, used a widely-available brand of combined estrogen -progestin contraceptive pills. $^{13}$ This regimen consists of two doses of $100 \mathrm{mcg}$ of ethinyl estradiol and $1.0 \mathrm{mg}$ of norgestrel taken 12 hours apart, with the first dose administered within 72 hours of unprotected intercourse. Other traditional oral contraceptives can be used "off-label" as EC when given in appropriate doses. There is now strong scientific evidence that the progestin-only formulation is more effective and has fewer side effects than the combined estrogen-progestin regimens. ${ }^{14-17}$ Plan B, a progestin-only formulation containing levonorgetrel, was approved by the FDA in July 1999. Plan B subsequently received approval for non-prescription availability for individuals 18 years of age and older. ${ }^{18}$ Plan B One-Step, a single-pill version, is now available. Next Choice, a generic version now available, has the same labeling instructions as Plan B.

Although the use of EC will not eliminate unintended pregnancies, modifying the prescription-only status was an important step forward in increasing EC access. ${ }^{5}$ The non-prescription status (described by some as "behind-the-counter" as a governmentissued proof of age is required prior to purchase) has reduced delays in obtaining EC. Faster access to EC can result in initiation of therapy sooner after unprotected intercourse which results in higher efficacy rates. ${ }^{19}$ Removing the prescription-only barrier to EC access for those 18 years and older in August 2006 therefore increases the potential of EC to reduce unintended pregnancy rates. In July 2009, the age limit was lowered to 17 years; females aged 16 and younger still require a prescription. $^{20}$ Continued efforts to raise the publics' as well as healthcare professionals' awareness and knowledge of EC are essential. ${ }^{4}$

Non-prescription EC status in the U.S. can potentially reduce healthcare expenditures in terms of physician costs as well as costs related to unintended pregnancies and abortions. ${ }^{21,22}$ However, unawareness and limited knowledge of EC seem to be additional barriers to widespread EC use. $^{23}$ In 2003, the Kaiser Family Foundation Survey reported that only $6 \%$ of women had ever used EC. ${ }^{24}$ An additional survey showed that EC awareness was lower among teens and minorities. ${ }^{25}$ More importantly, only a small fraction of women who were given advance provision of EC used it correctly. ${ }^{26,27}$

This study has two objectives: (1) to report if nonprescription EC availability impacted self-reported unintended pregnancy rates and (2) to assess women's knowledge and awareness of EC prior to and after non-prescription availability.

\section{METHODS}

\section{Data collection and instrument}

Data were collected from a cross-sectional, convenience sample of pregnant women who received routine prenatal care between August 2003 and October 2008 at a large urban community women's clinic in Little Rock, Arkansas. Verbal consent was obtained from each participant before the survey was administered. This study was approved by the governing Institutional Review Board under expedited review. Demographic information collected included age, income, education, race, gestational age, and obstetrical history (number of pregnancies, number of spontaneous or induced abortions, and previous pregnancy outcomes). The verbally-administered survey consisted of five questions concerning 
contraceptive use prior to pregnancy, intent to use contraceptives in the future, knowledge of EC pills, and women's feelings upon learning they were pregnant. Four pharmacy practice faculty members reviewed the survey instrument for relevance and completeness in an attempt to ensure content validity. The survey was pre-tested on four student pharmacists to make sure the questions were understandable and modified based on their questions and comments. The survey was originally designed as a tool to provide personalized contraception counseling to clinic patients. After verbal administration of the survey, each subject received individualized education based on her responses to the questions. A copy of the survey instrument is available from the corresponding author.

\section{Statistical Analysis}

The survey data were divided into two periods: before (August 2003 through December 2006) and after non-prescription EC availability (January 2007 through 2008). Although EC was approved for nonprescription status in August 2006, the manufacturer (Barr Laboratories) did not begin shipping the newly-designed packages of Plan B, labeled for both prescription and non-prescription use, to U.S. pharmacies until November 2007. For this reason, January 2007 was chosen as a cut-off point for designating the "after non-prescription availability" period. Descriptive analyses were used to characterize the study subjects' sociodemographic characteristics and survey responses. Differences among socio-demographics between the two time periods were tested using Chi-square test for categorical variables and t-test for continuous variables. An unintended pregnancy was identified if a subject answered the question "Thinking back to before you became pregnant, how did you feel about becoming pregnant?" by responding that she wanted to be pregnant later or did not want to be pregnant then or at anytime in the future. The Pearson Chi-square test and Fisher exact test were applied to explore associations between patients who reported intended and unintended pregnancy with different sociodemographic variables and reported knowledge and awareness of EC availability at a significance level of 0.05 . All statistical analyses were performed using SAS 9.2 (SAS Institute Inc, Cary, North Carolina).

\section{RESULTS}

A total of 272 patients completed the survey from August 2003 to December 2008. Approximately $44 \%$ were 19 years old or younger (Table 1 ).

\begin{tabular}{|c|c|c|c|c|c|}
\hline & $\mathrm{n}$ & Before $^{a}$ & $\mathrm{n}$ & After ${ }^{a}$ & $p$-value \\
\hline Average age (range, SD) & 170 & $24(15-40,5.5)$ & 102 & $17(13-40,3.4)$ & $<0.0001$ \\
\hline $\begin{array}{l}\text { Age range, } \mathrm{n}(\%) \\
\leq 19 \\
20-25 \\
26-30 \\
>30\end{array}$ & & $\begin{array}{l}23(13.5 \%) \\
85(50.0 \%) \\
41(24.1 \%) \\
21(12.4 \%)\end{array}$ & & $\begin{array}{c}95(93.1 \%) \\
4(3.9 \%) \\
2(2.0 \%) \\
1(1 \%)\end{array}$ & \\
\hline $\begin{array}{l}\text { Education level, n (\%) } \\
\text { High school or lower } \\
\text { Associate or college degree }\end{array}$ & $158^{\mathrm{C}}$ & $\begin{array}{l}127(80.4 \%) \\
31(19.6 \%)\end{array}$ & $99^{c}$ & $\begin{aligned} 93 & (93.9 \%) \\
6 & (6.1 \%)\end{aligned}$ & 0.0026 \\
\hline $\begin{array}{l}\text { Household income } \\
\leq \$ 20,000 \\
>\$ 20,000\end{array}$ & $151^{\mathrm{C}}$ & $\begin{array}{l}112(74.2 \%) \\
39(25.8 \%)\end{array}$ & $96^{\mathrm{c}}$ & $\begin{array}{c}94(97.9 \%) \\
2(2.1 \%)\end{array}$ & $<0.0001$ \\
\hline $\begin{array}{l}\text { Race/ethnicity } \\
\text { African-American } \\
\text { Caucasian } \\
\text { Hispanic } \\
\text { Others }\end{array}$ & 170 & $\begin{array}{c}73(42.9 \%) \\
78(45.8 \%) \\
17(10.0 \%) \\
2(1.2 \%)\end{array}$ & $102^{c}$ & $\begin{array}{c}65(63.7 \%) \\
17(16.7 \% \\
18(17.7 \%) \\
2(1.9 \%)\end{array}$ & $<0.0001$ \\
\hline Average gestational age (range, SD) & $161^{\mathrm{C}}$ & $\begin{array}{c}26.7 \\
(1-41,9.2)\end{array}$ & $99^{c}$ & $\begin{array}{c}27.3 \\
(1-40,8.2)\end{array}$ & $n s$ \\
\hline Number of pregnancies, mean (range) & $163^{\mathrm{C}}$ & $\begin{array}{c}2.6 \\
(1-11)\end{array}$ & $101^{\mathrm{c}}$ & $\begin{array}{c}1.3 \\
(1-4)\end{array}$ & $<0.0001$ \\
\hline $\begin{array}{l}\text { Number of pregnancies greater than } 20 \text { weeks } \\
\text { gestational age }\end{array}$ & $162^{\mathrm{C}}$ & $\begin{array}{c}1.1 \\
(0-10)\end{array}$ & $101^{\mathrm{c}}$ & $\begin{array}{c}0.2 \\
(0-3)\end{array}$ & $<0.0001$ \\
\hline $\begin{array}{l}\text { Pregnancy intention } \\
\text { Unintended } \\
\text { Intended }\end{array}$ & $33^{\mathrm{d}}$ & $\begin{array}{c}24(72.7 \%) \\
9(27.3 \%) \\
\end{array}$ & $97^{\circ}$ & $\begin{array}{c}88(90.7 \%) \\
9(9.3 \%) \\
\end{array}$ & 0.0172 \\
\hline \multicolumn{6}{|c|}{$\begin{array}{l}{ }^{a} \text { Before and After refer to time periods before and after availability of non-prescription emergency contraceptive (the cut-off point } \\
\text { was January 2007) } \\
\text { b Unintended pregnancy was identified if a patient reported that she wanted to be pregnant later or did not want to be pregnant then } \\
\text { or at any time in the future. } \\
{ }^{c} \text { Missing data } \\
{ }^{d} \text { The question of pregnancy intention was added in the survey near the end of the Before period which reflected a small number of } \\
\text { respondents. } \\
n=\text { number of respondents } \\
S D=\text { Standard deviation } \\
\text { All the p-values were calculated from Chi-square statistic or Fisher exact test when appropriate for educational level, household } \\
\text { income, and race/ethnicity and from } t \text {-test (Satterthwaite Method was used for unequal variances) for age, gestational age, number } \\
\text { of pregnancies, number of pregnancies that have progressed longer than } 20 \text { weeks, and number of abortion. } \\
n s=\text { non-significant difference }\end{array}$} \\
\hline
\end{tabular}


Payakachat N, Ragland D, Houston C. Impact of emergency contraception status on unintended pregnancy: observational data from a women's health practice. Pharmacy Practice (Internet) 2010 Jul-Sep;8(3):173-178.

\begin{tabular}{|c|c|c|c|c|c|}
\hline & $n$ & Before $^{a}$ & $n$ & After $^{a}$ & $p$-value ${ }^{b}$ \\
\hline & & $\mathrm{n}(\%)$ & & n (\%) & \\
\hline $\begin{array}{l}\text { Using birth control at time of conception } \\
\text { Yes } \\
\text { No }\end{array}$ & 170 & $\begin{array}{c}26(15.3 \%) \\
144(84.7 \%)\end{array}$ & 102 & $\begin{array}{l}17(16.7 \%) \\
85(83.3 \%)\end{array}$ & $n s$ \\
\hline $\begin{array}{l}\text { Reported using contraception in the past } \\
\text { Yes } \\
\text { No }\end{array}$ & $121^{\mathrm{C}}$ & $\begin{array}{l}89(73.6 \%) \\
32(26.4 \%)\end{array}$ & 102 & $\begin{array}{l}49(48.0 \%) \\
53(52.0 \%)\end{array}$ & $<0.0001$ \\
\hline $\begin{array}{l}\text { Plan to use contraception after this pregnancy } \\
\text { Yes } \\
\text { No }\end{array}$ & $160^{c}$ & $\begin{array}{c}147(91.9 \%) \\
13(8.1 \%)\end{array}$ & $91^{c}$ & $\begin{array}{l}79(86.8 \%) \\
12(13.2 \%)\end{array}$ & ns \\
\hline $\begin{array}{l}\text { Aware of emergency contraceptive pills } \\
\text { Yes } \\
\text { No }\end{array}$ & $169^{c}$ & $\begin{array}{l}79(46.8 \%) \\
90(53.2 \%)\end{array}$ & $100^{c}$ & $\begin{array}{l}43(43.0 \%) \\
57(57.0 \%)\end{array}$ & ns \\
\hline $\begin{array}{l}\text { Would consider using emergency contraceptive pills in the future } \\
\text { Yes } \\
\text { No }\end{array}$ & $148^{c}$ & $\begin{array}{l}79(53.4 \%) \\
69(46.6 \%)\end{array}$ & $88^{c}$ & $\begin{array}{c}56(63.4 \%) \\
32(36.4 \%\end{array}$ & ns \\
\hline \multicolumn{6}{|c|}{$\begin{array}{l}\text { Before and After refer to time periods before and after availability of non-prescription emergency contraception (the cut-off point } \\
\text { was January 2007) } \\
{ }^{\mathrm{b}} \text { All the p-values were calculated from Chi-square statistic } \\
\text { cMissing data } \\
n s=\text { non-significant difference }\end{array}$} \\
\hline
\end{tabular}

There were 170 participants in the "before nonprescription EC availability" group (BA) and 102 in the "after" group (AA). The average age of the AA group was younger than the BA group (17 vs. 24, $\mathrm{P}<0.0001)$. There were significant differences in education level, household income, race/ethnicity, obstetric history, and pregnancy intention between the two groups $(P<0.05)$. Ninety-four percent of patients in the $A A$ group reported their educational levels as high school or lower when compared to the BA group $(80.4 \%)$. Only $2 \%$ of the patients in the AA group reported their incomes higher than USD20,000 when compared to the BA group $(25.8 \%)$. Interestingly, there were more patients in the AA group who reported unintended pregnancy when compared to the BA group $(90.7 \%$ vs. $72.7 \%$, $\mathrm{P}=0.0172$ ). The majority of the patients in both periods reported that they were not using any form of birth control at the time of conception (84.4\% BA and $83.3 \% \mathrm{AA}$ ), but they were willing to use birth control in the future $(91.9 \% \mathrm{BA}$ and $86.8 \% \mathrm{AA}$; Table 2). The most popular choices of birth control were tubal ligation, (18\%), oral contraceptives (15\%), and depot injection (14\%). All women who reported intent to use sterilization were in the BA group. The most common reasons for stopping contraception were adverse reactions or conception while using their preferred method of birth control (Table 3). Of the 269 respondents who answered the question regarding knowledge of EC, only $45 \%$ knew about "pills that could prevent pregnancy after unprotected intercourse." There was no significant difference in awareness between the $\mathrm{BA}$ and $\mathrm{AA}$ groups $(46.8 \%$ vs. $43.0 \%)$ or the willingness to use EC in the future $(53.1 \%$ vs. $63.4 \%$, Table 2$)$. However, among participants who were unaware of EC, $61 \%$ of reported they would consider using it in the future after receiving EC information from a pharmacy student. Neither age nor number of pregnancies was associated with self-reported EC awareness but there was an association between awareness and the patient characteristics of income $(P=0.0410)$ and education $(P=0.0021)$. Of all participants, the average age of the patients with an unintended pregnancy was 17.7 years $(85.7 \%$ were younger than 20 years of age). The majority of the participants $(60.7 \%)$ were African-American and $97 \%$ of all subjects reported a low income (Table 4 ).

Table 3. Reported reasons for stopping contraception (110 patients)

\begin{tabular}{|l|l|}
\hline \multicolumn{1}{|c|}{ Reasons } & \multicolumn{1}{c|}{$\mathrm{N}(\%)$} \\
\hline Side effects & $46(41.8 \%)$ \\
\hline Missed clinic visit & $15(13.6 \%)$ \\
\hline Cost & $4(3.6 \%)$ \\
\hline Attempting pregnancy & $10(9.1 \%)$ \\
\hline Got pregnant & $29(26.4 \%)$ \\
\hline Wanted to quit & $6(5.5 \%)$ \\
\hline
\end{tabular}

\section{DISCUSSION}

This study explored the impact of non-prescription EC availability on unintended pregnancy rates among a convenience sample of parents receiving prenatal care at a women's health practice in Little Rock, Arkansas. The switch to non-prescription status of Plan B was an important first step in increasing timely access to EC for patients 17 years and older. However, the results of this study show that the number of self-reported unintended pregnancies is still high despite the availability of non-prescription EC. More importantly, the results show that lack of awareness and knowledge of EC remains a major barrier to appropriate EC use in this patient population. These findings are similar to previous studies. ${ }^{25,28-31}$ The EC awareness among women was not significantly different after the EC prescription status change; similar findings were observed in Finland and Australia. ${ }^{32,33}$ The number of patients who reported having an abortion was smaller after non-prescription EC availability and this finding is consistent with another report. ${ }^{34}$ However, this result may be biased due to the age difference between the two groups; the participants in the AA group were significantly younger than the $B A$ group. The unintended pregnancy rates in both groups $(72.7 \%$ in $B A$ and $90.7 \%$ in $A A)$ were substantially higher than the national trend of $41 \% .{ }^{1}$ 


\begin{tabular}{|c|c|c|}
\hline & $\mathrm{n}$ & \\
\hline Average Age (range, SD) & 112 & $\begin{array}{c}17.7 \\
(13-40,4.1)\end{array}$ \\
\hline $\begin{array}{l}\text { Age range, } \mathrm{n}(\%) \\
\leq 19 \\
20-25 \\
26-30 \\
>30\end{array}$ & & $\begin{array}{l}96(85.7 \%) \\
9(8.0 \%) \\
5(4.5 \%) \\
2(1.8 \%) \\
\end{array}$ \\
\hline $\begin{array}{l}\text { Education level } \\
\text { High school or lower } \\
\text { Associate or college degree }\end{array}$ & $109^{b}$ & $\begin{array}{c}99(90.8 \%) \\
10(9.2 \%) \\
\end{array}$ \\
\hline $\begin{array}{l}\text { Household income } \\
\leq \$ 20,000 \\
>\$ 20,000\end{array}$ & $105^{b}$ & $\begin{array}{c}97(92.4 \%) \\
8(7.6 \%)\end{array}$ \\
\hline $\begin{array}{l}\text { Race/ethnicity } \\
\text { African-American } \\
\text { Caucasian } \\
\text { Hispanic } \\
\text { Others } \\
\end{array}$ & 112 & $\begin{array}{c}68(60.7 \%) \\
25(22.3 \%) \\
17(15.2 \%) \\
2(1.8 \%) \\
\end{array}$ \\
\hline $\begin{array}{l}\text { Average gestational age } \\
\text { (range, SD) }\end{array}$ & $109^{b}$ & $26.7(1-40,8.3)$ \\
\hline $\begin{array}{l}\text { Average number of } \\
\text { pregnancies (range, SD) }\end{array}$ & $111^{b}$ & $1.4(1-6,0.9)$ \\
\hline \multicolumn{3}{|c|}{$\begin{array}{l}\text { Unintended pregnancy was identified if a patient reported that } \\
\text { she wanted to be pregnant later or did not want to be pregnant } \\
\text { then or at any time in the future } \\
{ }^{b} \text { Missing data } \\
\text { SD = Standard deviation }\end{array}$} \\
\hline
\end{tabular}

Based on patients' answers regarding future use of EC, counseling by a pharmacist has great potential to improve patient awareness which may subsequently decrease unintended pregnancies among this patient population. Given that approximately $90 \%$ of the patients served at this clinic site receive Arkansas Medicaid, even a slight decrease in the number of unintended pregnancies can save substantial public health care dollars in addition to the significant physical, emotional, and economical costs to the individual patients.

Now that retail pharmacies are a major source of EC distribution, pharmacists are in a pivotal role to provide contraception counseling and education. $^{33,35,36}$ Because of this, it is imperative that pharmacists themselves are knowledgeable about EC and handle EC requests appropriately; unfortunately, this is not always the case. ${ }^{37-39}$ Although consultation with a pharmacist is not required for the behind-the-counter version of EC; not providing counseling would be a missed opportunity for patient education.

\section{Limitations}

There are several limitations to this study. Most importantly, the data were drawn from a crosssectional convenience sample rather than a random sampling technique. The number of unintended pregnancies in this sample may not represent the actual rate of unintended pregnancies at the practice site or in the general population. Additionally, the study was conducted at a single location in Arkansas and consequently, the findings may not be generalizable to all U.S. pregnant women. The clinic used as the study site generally serves women in a low economic bracket; approximately $90 \%$ of these patients receive Arkansas Medicaid. It is possible that a convenience sample of a higher income level would have vastly different results. As a result, study results may not accurately reflect the knowledge and awareness of EC as well as the impact of EC status on unintended pregnancy.

\section{CONCLUSIONS}

It appears that knowledge and awareness of EC did not increase in this patient population since the change in status of non-prescription EC. The findings from this study should be confirmed with additional, longitudinal studies. Effectiveness of pharmacy counseling on EC and other contraception use is another topic that warrants future investigation.

\section{CONFLICT OF INTEREST}

The authors declare no conflicts of interest or financial interests in any product or service mentioned in this article including grants, employment, gifts, stock holdings or honoraria.

\section{References}

1. Pregnancy Risk Assessment Monitoring System (PRAMS). PRAMS and Unintended Pregnancy. http://www cdc gov/PRAMS/UP htm 2009 February 4;Available at: URL: http://www.cdc.gov/PRAMS/UP.htm. AccessedAugust 10, 2009.

2. Santelli J, Rochat R, Hatfield-Timajchy K, Gilbert BC, Curtis K, Cabral R, Hirsch JS, Schieve L; Unintended Pregnancy Working Group. The measurement and meaning of unintended pregnancy. Perspect Sex Reprod Health. 2003;35(2):94101

3. Henshaw SK. Unintended pregnancy in the United States. Fam Plann Perspect. 1998;30(1):24-9, 46.

4. Trussell J, Ellertson C, Stewart F, Raymond EG, Shochet T. The role of emergency contraception. Am J Obstet Gynecol. 2004;190(4 Suppl):S30-S38.

5. Steinbrook R. Waiting for Plan B -- The FDA and Nonprescription Use of Emergency Contraception. N Engl J Med. 2004;350(23):2327-2329.

6. Kuroki LM, Allsworth JE, Redding CA, Blume JD, Peipert JF. Is a previous unplanned pregnancy a risk factor for a subsequent unplanned pregnancy? Am J Obstet Gynecol. 2008;199(5):517.

7. Phipps MG, Matteson KA, Fernandez GE, Chiaverini L, Weitzen S. Characteristics of women who seek emergency contraception and family planning services. Am J Obstet Gynecol. 2008;199(2):111-115.

8. The Guttmacher Institute. Contraception counts: Arkansas. http://www guttmacher org/pubs/state_data/states/arkansas html 2006 March. Accessed September 28, 2009. 
9. Brown S, Eisenberg L. The best intentions: unintended pregnancy and the well-being of children and families. Washington (DC): National Academy Press; 1995.

10. Westhoff C. Emergency Contraception. N Engl J Med. 2003;349(19):1830-1835.

11. Amaral G, Foster DG, Biggs MA, Jasik CB, Judd S, Brindis CD. Public savings from the prevention of unintended pregnancy: a cost analysis of family planning services in California. Health Serv Res. 2007;42(5):1960-1980.

12. Weisberg E, Fraser IS. Rights to emergency contraception. Int J Gynaecol Obstet. 2009;106(2):160-163.

13. Yuzpe AA, Thurlow HJ, Ramzy I, Leyshon JI. Post coital contraception--A pilot study. J Reprod Med. 1974;13(2):53-58.

14. Task Force on Postovulatory Methods of Fertility Regulation. Randomized controlled trial of levonorgestrel versus the Yuzpe regimen of combined oral contraceptives for emergency contraception. Lancet. 1998;352(9126):428-433.

15. Raymond E, Taylor D, Trussell J, Steiner MJ. Minimum effectiveness of the levonorgestrel regimen of emergency contraception. Contraception. 2004;69(1):79-81.

16. Ho PC, Kwan MS. A prospective randomized comparison of levonorgestrel with the Yuzpe regimen in post-coital contraception. Hum Reprod. 1993;8(3):389-392.

17. Cheng L, Gulmezoglu AM, Oel CJ, Piaggio G, Ezcurra E, Look PF. Interventions for emergency contraception. Cochrane Database Syst Rev. 2004;(3):CD001324.

18. Ranney ML, Gee EM, Merchant RC. Nonprescription availability of emergency contraception in the United States: current status, controversies, and impact on emergency medicine practice. Ann Emerg Med. 47[5], 461-471. 5-1-2006.

19. Espey E, Ogburn T, Fotieo D. Contraception: What Every Internist Should Know. Med Clin North Am. 2008;92(5):10371058.

20. U.S.Food and Drug Administration. FDA approves Plan B one-step emergency contraceptive; lowers age for obtaining two-dose Plan B emergency contraceptive without a prescription. http://www fda gov/Drugs/DrugSafety/PostmarketDrugSafetyInformationforPatientsand Providers/UCM109775 2009 July 16. Accessed September 28, 2009.

21. Trussell J, Koenig J, Ellertson C, Stewart F. Preventing unintended pregnancy: the cost-effectiveness of three methods of emergency contraception. Am J Public Health. 1997;87(6):932-937.

22. Trussell J, Stewart $F$, Guest $F$, Hatcher RA. Emergency contraceptive pills: a simple proposal to reduce unintended pregnancies. Fam Plann Perspect. 1992;24(6):269-273.

23. Rocca CH, Schwarz EB, Stweart FH, Darney PD, Raine TR, Harper CC. Beyond access: Acceptability, use and nonuse of emergency contraception among young women. Am J Obstet Gynecol. 2007;196(1):29.e1-6.

24. The Kaiser Family Foundation. Women's health care providers experiences with emergency contraception. 2003 Jun.

25. Baldwin SB, Solorio R, Washington DL, Yu H, Huang YC, Brown ER. Who is Using Emergency Contraception? Awareness and use of emergency contraception among California women and teens. Womens Health Issues. 2009;18(5):360-368

26. Jackson RA, Schwarz EB, Freedman L, Darney P. Advance supply of emergency contraception: effect on use and usual contraception--a randomized trial. Obstet Gynecol. 2003;102(1):8-16.

27. Endres LK, Beshara M, Sondheimer S. Experience with self-administered emergency contraception in a low-income, inner-city family planning program. J Reprod Med. 2000;45(10):827-830.

28. Crosier A. Women's knowledge and awareness of emergency contraception. Br J Fam Plann. 2006;22(2):87-90.

29. Foster DG, Harper CC, Bley JJ, Mikanda JJ, Induni M, Saviano EC, Stewart FH. Knowledge of emergency contraception among women aged 18 to 44 in California. Am J Obstet Gynecol. 2004;191(1):150-156.

30. Merchant RC, Casadei K, Gee EM, Bock BC, Becker BM, Clark MA. Patients' Emergency Contraception Comprehension, Usage, and View of the Emergency Department Role for Emergency Contraception. J Emerg Med. 2007;33(4):367-375

31. Cremer M, Holland E, Adams B, Klausner D, Nichols S, Ram RS, Alonzo TA. Adolescent comprehension of emergency contraception in New York City. Obstet Gynecol. 2009;113(4):840-844.

32. Falah-Hassani K, Kosunen E, Shiri R, Rimpelä A. Emergency contraception among Finnish adolescents: awareness, use and the effect of non-prescription status. BMC Public Health. 2007;7:201.

33. Hobbs M, Taft AJ, Amir LH. The emergency contraceptive pill rescheduled: a focus group study of women's knowledge, attitudes and experiences. J Fam Plann Reprod Health Care. 2009;35(2):87-91.

34. Finer LB, Henshaw SK. Disparities in rates of unintended pregnancy in the United States, 1994 and 2001. Perspect Sex Reprod Health. 2006;38(2):90-96.

35. Black K, Anderson C, Kubba A, Wellings K. Involving pharmacists in sexual health research: experience from an emergency contraception study. J Fam Plann Reprod Health Care. 2009;35(1):41-43.

36. Monastersky N, Landau SC. Future of emergency contraception lies in pharmacists' hands. J Am Pharm Assoc (2003). 2006;46(1):84-88.

37. Hopkins D, West D. Arkansas pharmacists perceptions toward emergency contraception and nonprescription Plan B. Pharm Pract (Internet). 2008;6(2):98-102.

38. Landau S, Besinque K, Chung F, Dries-Daffner I, Maderas NM, McGhee BT, Foster DG. Pharmacist interest in and attitudes toward direct pharmacy access to hormonal contraception in the United States. J Am Pharm Assoc (2003). 2009;49(1):43-50.

39. Sutkin G, Grant B, Irons BK, Borders TF. Opinions of West Texas pharmacists about emergency contraception. Pharm Pract (Internet). 2006;4(4):151-155. 